\title{
APPLICATION OF PLAYING METHOD MOBIS TO GROW-BUILD A FINE MOTORIC SKILL AND CREATIVITY OF PRESCHOOL AGE (5-6 years) THROUGH MOBILE ACTIVITIES IN ISLAMIC KINDERGARTEN AN-NISA BANDUNG
}

\author{
${ }^{1}$ Efi Muftiati, ${ }^{2}$ Euis Eti Rohaeti, ${ }^{3}$ Nandang Rukanda
}

1,2,3 IKIP Siliwangi

\begin{abstract}
Implementation of play methods in early childhood has always been a major effort in foster-growinga fine motor skills and creativity. In An-Nisa Bandung kindergarten, the method of playing through Mobis (Motor skills block interlocking system) activities is applied to 20 B-age group students aged 5-6 years to know the success rate of developing motor skills and creativity after 8 times of monitoring in the class. The results of the experimental experiments show a smooth growth rate of fine motor skills average of $70 \%$ or included in the category "Growing as the hope" and the average creativityof $85 \%$ which belongs to the category "Growing very good". Evaluation of the effectiveness of Mobis method implementation shows more correction or refinement result about parameters of the number of applications within the specified time period that best suits the psychological situation of the students. The other improvements are statistically mainly about the number of students who should be more and come from various backgrounds of family culture, as well as supporting facilities in class activities and the number of teachers and teacher assistants who monitor.
\end{abstract}

Keyword : playing methods, motoric and creativity, mobile activities

\section{INTRODUCTION}

Early Childhood Education (PAUD) based on RI Law no. 20 of 2003 on the national education system, defined as a conscious and planned effort to create an atmosphere of learning and learning process to children aged 0 to 6 years actively and creatively in order to have the emotional and spiritual intelligence, and intellectual intelligence needed for himself, country (Book of RI Law No. 20 of 2003, Yamin, et al, 2010; Wiyani, NA, 2016). In the early childhood learning process there are three main stages: infant stage (0-12 months), "under five years" / toddler (1-3 years) and preschool (3-6 years) stages; which is where the preschool stage is the most sensitive period of information intake from its environment or education. This sensitivity will greatly affect the process and the results of growth in the fine motor aspects and the creativity of preschoolers. Whereas in the stages of infants and toddlers, it is more dominated by physical growth which is increasingly elongated and enlarged, and only relatively few experience psychic development.

As the authors compile from the opinions of experts on the notion of 'fine motor' that is the organizing movement that involves only certain parts of the body using small muscles by carefully coordinating with the eyes, hands and fingers (Hurlock, EB, 1978, Santrock, WJ, 1995; Sumantri, MS, 2005; Sujiono, et al, 2009 \& Noorlaila, I., 2010); hence 
the application of appropriate stimulus methods to children in the preschool stage can be said to be obligations that must be implemented by educational institutions or kindergartens in the modern society. Furthermore, the implementation of fine motor development itself at preschool age (4-6 years) aims to achieve the following abilities (Sumantri, M.S., 2005):

a. The child is able to develop fine motor skills related to the motion skills of both hands.

b. Able to move the limbs associated with fine motor skills related to fingers, such as: readiness to write, draw, and manipulate objects.

c. Able to coordinate hand and eye speed,

d. able to control emotions in smooth motor creativity.

While Yudha M. Saputra \& Rudyanto (2005) mentioned there are some goals of fine motor development of children are as follows:

a. Able to function small muscles such as finger movements.

b. Able to coordinate hand and eye speed.

c. Be able to control emotions.

From the two opinions above can be concluded that the purpose of fine motor development of children in this study is the child is able to Develop the skills of hand movement, especially the fingers, children able to coordinate the speed of the eyes and hands, and able to control the emotions. The purpose of fine motor development in this study is the child is able to move the smooth muscles of the finger and hand eye coordination to perform activities such as stringing some components of educational play tools Mobis (Motor Skills Block Interlocking System) into a meaningful symbolic form. The right selection of stimulus methods must be based first on the results of evaluating experiences from the application of playing methods that have been applied before.

As for the notion of 'early childhood creativity', the author refers more to the opinions of experts that can be summarized as follows: Creativity is the ability to create something new from the interaction between the individual and his environment which is a combination of various experiences throughout his life including education gained Semiawan, CR, 2009; Munandar, U., 2009 \& Ngalimun, et al., 2013). From this sense we can derive some general indicators as creative children, that is: have a strong imagination, have initiative, have wide interest, free in thinking (not rigid and inhibited), are inquisitive, always want to get experience - new experiences, selfconfidence, eager, risk-taking (not afraid to make mistakes), and dare to express opinions with confidence (no doubt in expressing opinions despite criticism and dare to defend opinions that became his belief).

As stated above, the implementation of "play method" in early childhood is an implementation obligation in kindergarten schools as the optimal way for growth of motor and creativity aspects. So with the many types of games and play tools that producers have developed, kindergarten schools have been able to choose the most appropriate, according to the needs of the students in the circle and the culture of a particular community. For that let us review in advance the basic notions of play itself 
which the author summarized from various definitions compiled by educational psychologists, namely: 'play' is an activity carried out by children repeatedly with the intention of having fun, which also functions as a medium to improve cognitive development of children (Tejasaputra, 2005; Hariwijaya, 2009; Piaget, 2010; Vigotsky, 2010). It is also said that early childhood in playing is also interested in particular in the symbolic and imaginary aspects of a game (Vigotsky, 2010). From the notion of 'playing' above, it can be extracted the dominant factors of the child's behavior just before playing, when play and moments after playing. Before playing, spontaneously-sporadic enthusiasts who then play games, when playing are often repeated activities so that they memorize the ways to play and also become more skillful in motoric behavior, and when after playing the child will increase his understanding (cognitive) game symbols and also increased the power of imaginary thinking or creativity. Therefore, specifically for fine motoric aspects and early childhood creativity, this playing activity can be used as a medium for the application of playing tools or methods that provide more stimulus for fine motor development and creativity of preschoolers.

\section{Background Problems and Hypotheses}

The progress of the current era that has reached the millennial century with information technology hegemony that penetrates all corners of the hemisphere, with no exception occurring in the archipelago of the Republic of Indonesia, which involves all people from the early age groups to retired parents. This level of progress has certainly increased the demands of society's capacity that should be in line with the progress of civilization. Therefore, various 'preparations', especially in the field of early childhood education, especially at the preschool stage, should be carried out as targeted and effective as possible in the implementation of their learning. In this preschool stage where fine motorbike and creativity are two of the most important aspects that must be developed, if it is associated with the demands of the progress of civilization, the formulation of important things can be the reason for having to choose a method that is more effective and on target, namely:

1. Preschool stages (3 - 6 years) are age levels where early childhood experience maximum sensitivity to information and other environmental influences that will affect the process and results of child growth and development,

2. Therefore, the activities of fine motor learning and creativity as an early stage of early childhood development are very important factors to be implemented in kindergarten education institutions.

3. The need to make an effort to select playing media that provides more stimulus carefully so that it can produce the development of fine motor skills and children's creativity that is most optimal in facing the challenges of further life in modern times.

To answer the above three things which are the background of the problems in modern times, it is necessary to build a theoretical hypothesis that is expected to be implemented and produce solutions to these problems. The hypothesis is to test the more advanced play methods such as Mobis play (Motor skills block interlocking system); which is definitively an educational tool to train subtle motorics and children's creativity and help children to be smarter, confident, independent, strong in socializing, have a high level of curiosity, creative, innovative and ready to go higher. The success of 
this hypothesis is expected to be a testimonial or model for the application of more effective play methods in the future.

\section{Location, Time and Objectives}

This research is conducted by the author by taking the location in An-Nisa kindergarten which is located at Jalan Jenderal Sudirman No. 819 Bandung (figure 1), with the implementation of observation data retrieval as many as 8 meetings in the class from January to March 2018. Aims to get an overview and further understanding of the level of success of the application of the playing method using Mobis play equipment in preschoolers aged 5 - 6 years.
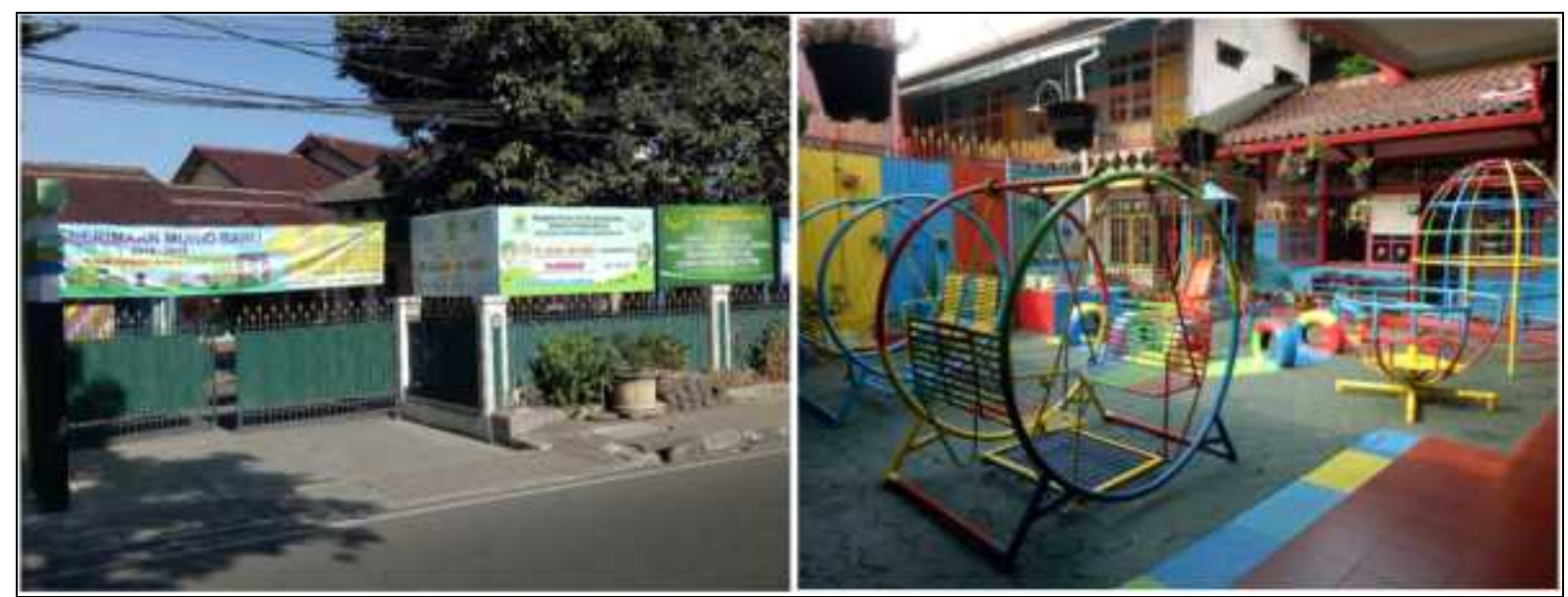

Figure 1. Research location at An-Nisa Kindergarten, Jl. Jend. Sudirman 819 Bandung (on the left), and the atmosphere of the playground (on the right).

\section{METHOD ARRANGEMENT OF STUDENT DATA SAMPLING}

This research uses qualitative-descriptive research method, which then is done by interpretation of curve of observation result. It is said 'qualitative' because in its analysis is based only on the rise and fall of the curve of the observed parameters plotted in the diagram, without calculating the mathematical formula. In each analysis is always accompanied by considerations of the results of the description of the students' subjects. The subject of this research is the method of playing by using a Mobis playing tool, which is a kind of beam play equipment that will be arranged "interlocking" into a creative and symbolic meaning of larger and / or higher meaning (figures $2 \& 3$ ). 


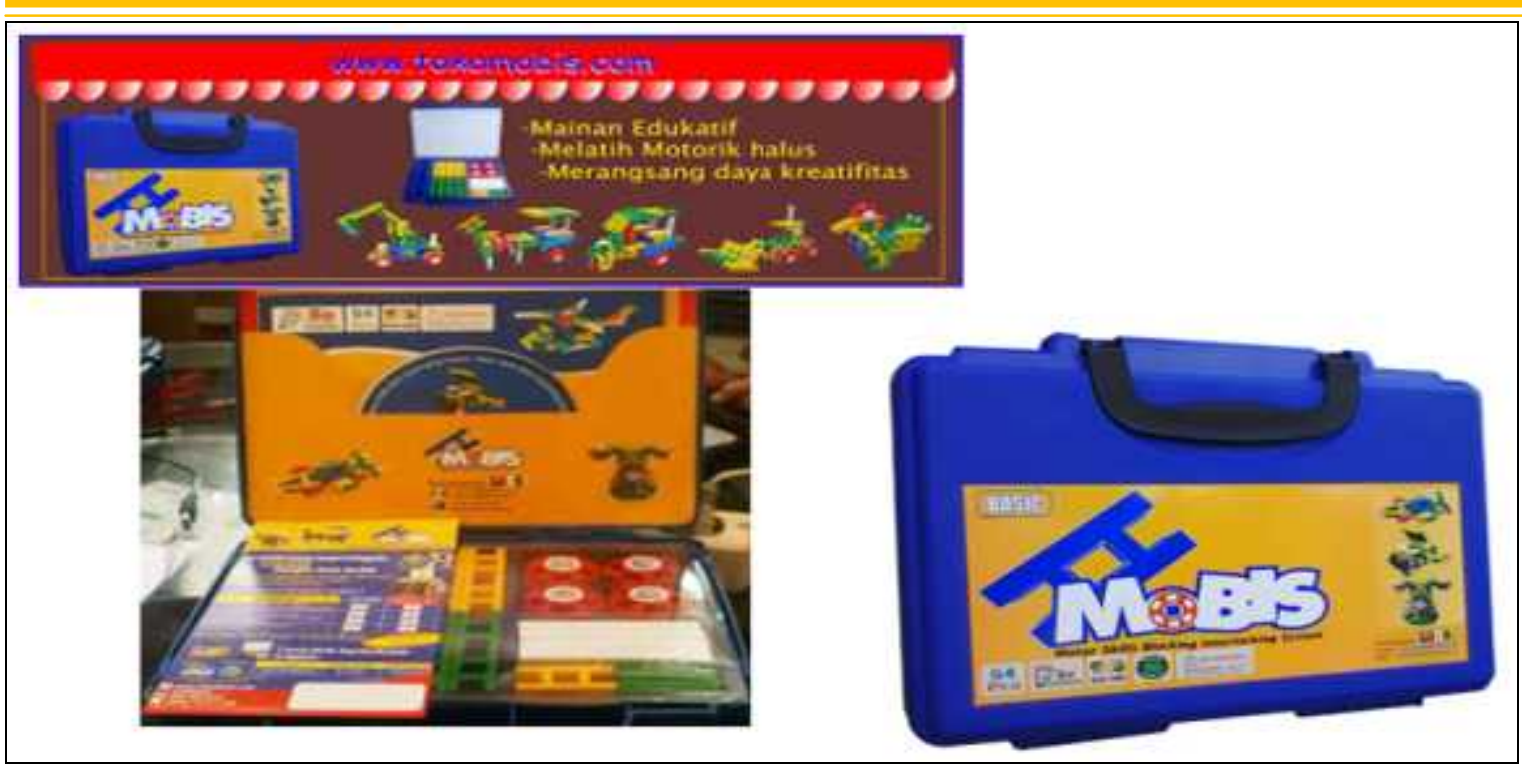

Figure 2. Mobis play tools (Motor Skills Block Interlocking System)

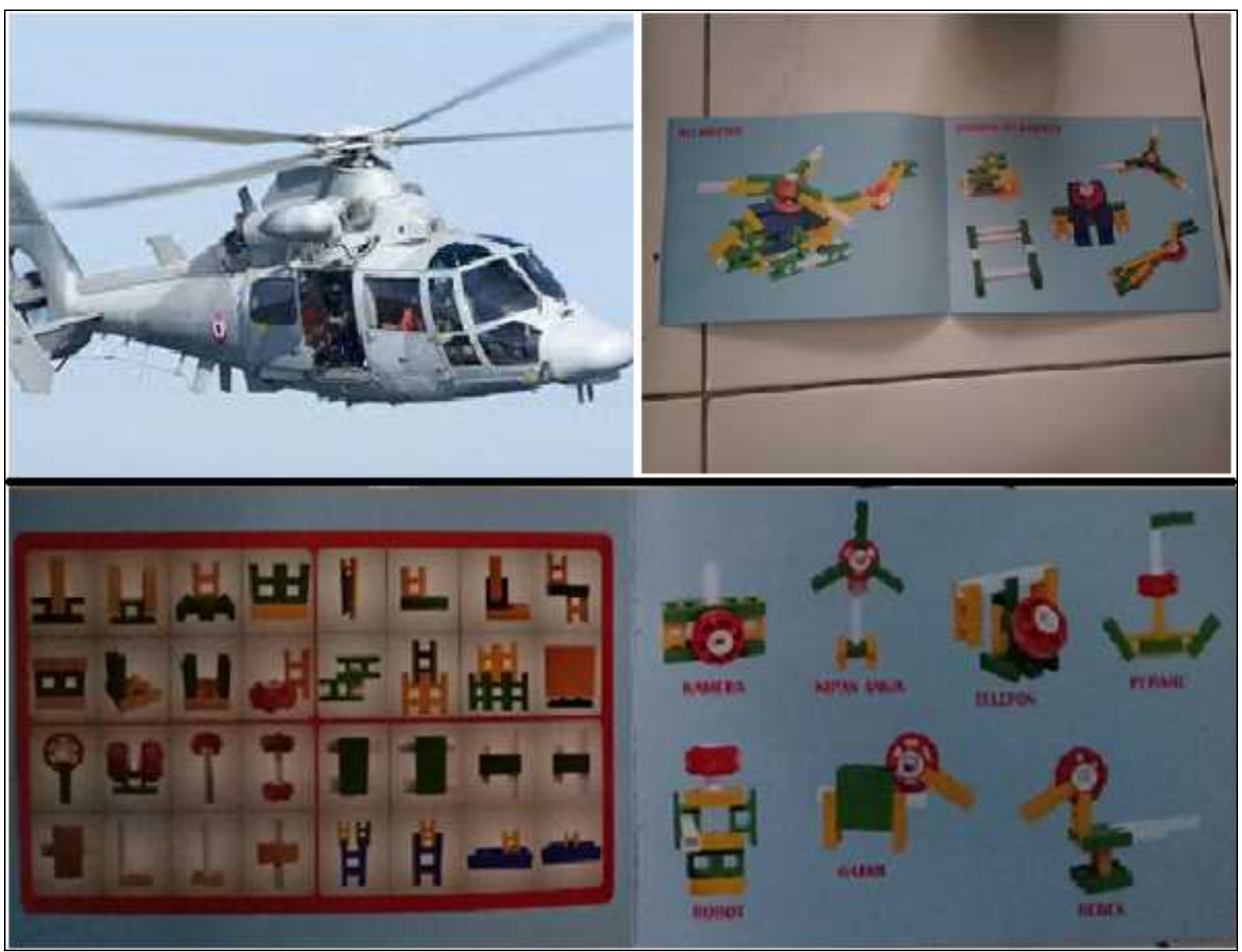

Figure 3. Mobis guidebook that describes the symbolic reconstructions of helicopter, camera, fan, telephone, boat, robot, elephant and duck; with various forms of Mobis beams needed to assemble them. 
This research method is designed to observe progress on the main variable of fine motor, creativity and understanding of Mobis playground, where each variable is monitored on various derivative indicators (table 1).

Table 1. List of Indicators of each Variable to be observed progress

\begin{tabular}{|l|l|l|}
\hline No & \multicolumn{1}{|c|}{ Variable } & \multicolumn{1}{c|}{ Indicator } \\
\hline 1 & $\begin{array}{l}\text { Fine motoric } \\
\text { skill } \\
\text { (Optimizing the } \\
\text { use of hand and } \\
\text { finger muscles) }\end{array}$ & $\begin{array}{l}\text { 1. Taking components and installing components as } \\
\text { directed. } \\
\text { 2.Able to disconnect and restore components correctly } \\
\text { according to directions. } \\
\text { 3. Able to make forms according to direction } \\
\text { 4. Able to make shape gradually until finished. }\end{array}$ \\
\hline 2 & Creativity & $\begin{array}{l}\text { 1. Able to beride create their own shape } \\
\text { 2. Able to use at least 5 Mobis components } \\
\text { 3. Be able to name names of self-made form } \\
\text { 4.Able to create your own form with various variations }\end{array}$ \\
\hline 3 & Mobis & $\begin{array}{l}\text { 1. Does the child know Mobis? } \\
\text { 2. Can the child mention the name and part of the mobis } \\
\text { component? } \\
\text { 3. Does the child have an interest in Mobis? } \\
\text { 4. Does the child last a long time playing the Mobis? }\end{array}$ \\
\hline
\end{tabular}

The observation in An-Nisa kindergarten class was held for 8 meetings in January to March 2018 or once a week. Observation results are expressed in numbers 1 to 4 which represent the following four success categories:

1 = BB (Undeveloped), $2=\mathrm{MB}$ (Start to Grow), $3=\mathrm{BSH}$ (Growing as Expected) \& $4=$ BSB (Developing Very Good).

\section{Selection of Mobis Methods}

Mobis play equipment is chosen by the author as the subject of research due to its existence which is not at all dangerous for children and with very light weight and colors that appeal to the child. From the author's observation, this playground has advantages and disadvantages as follows;

\section{The advantages:}

1.Mobis made of material safe for children

2. The color is interesting so the kids are more happy

3. The quality of the material is standard / not easily damaged

4. Media playing tools that are good for developing fine motor skills (training the fingers muscles 
5. Improving children's creativity (creating constructive form and pouring children's imagination in real form)

6. Emotional social train the child in terms of patience, responsibility, foster selfconfidence, concentration of hands)

\section{Disadvantages:}

1. The price is expensive

2. Not sold freely on the market

3. Still limited to big cities.

The steps of the implementation of Mobis Playing Methods in the class are as follows:

- Opening:

a. Regards

b. Greetings / Questions about the activities of students before coming to school

c. Reviewed material before

d. Submitting today's material through guesses, stories, songs or moral messages that the teacher wants to convey on that day.

e. Promise mobis (train responsibility and discipline when making shapes

- Fill in the Core Materials / Activities:

a. Distribution of mobility tools

b. Warm-up (finger exercises or body exercises)

c. Forming according to theme with 30 minutes

d. Ice breaking (an activity / movement to restore the child's concentration)

- Activities:

a. Play together

b. Children's presentation (Children mention / explain about the form made)

c. Imagine with the created shape

d. The teacher went around doing the assessment

- Closing:

a. Spruce up Mobis playground

b. Impression message

c. Review a little material next week.

The total duration of time required for all these steps is one hour. The observation activities are carried out using the same standard format every day for each monitoring of fine motor progress (see example in table 2) and creativity (see example in table 3) for all student participants. 
Table 2. Examples of fine motor observation formats used during the first 4 class meetings.

\begin{tabular}{|c|c|c|c|c|c|c|}
\hline \multicolumn{7}{|c|}{$\begin{array}{c}\text { Sheet of Mobis Fine Motoric Smooth Observation } \\
\text { Class B Fatimah } \\
\text { Islamic An-Nisa Kindergarten Bandung } \\
\text { First meeting }\end{array}$} \\
\hline \multirow{2}{*}{ No } & \multirow{2}{*}{ Name of puple } & \multirow{2}{*}{$\begin{array}{l}\text { Optimize the use of finger and } \\
\text { hand muscles (able to take } \\
\text { and install components as } \\
\text { directed }\end{array}$} & BB & MB & BSH & BSB \\
\hline & & & 1 & 2 & 3 & 4 \\
\hline 1 & Akmal Naufal F & & & & $\checkmark$ & \\
\hline 2 & Fadli & & & $\checkmark$ & & \\
\hline 3 & Fathiya & & & & & $\checkmark$ \\
\hline 4 & Bagas & & & & $\checkmark$ & \\
\hline 5 & Hasya & & & & $\checkmark$ & \\
\hline 6 & Azka & & & & $\checkmark$ & \\
\hline 7 & Ghailan & & & & & $\checkmark$ \\
\hline 8 & Alarick & & & & $\checkmark$ & \\
\hline 9 & Sabiq & & & $\checkmark$ & & \\
\hline 10 & Mutia & & & & $\checkmark$ & \\
\hline 11 & Naura & & & & $\checkmark$ & \\
\hline 12 & Naurah & & & $\checkmark$ & & \\
\hline 13 & Putri & & & & $\checkmark$ & \\
\hline 14 & Raja & & & $\checkmark$ & & \\
\hline 15 & Vale & & & $\checkmark$ & & \\
\hline 16 & Wangsa & & & & $\checkmark$ & \\
\hline 17 & Jian & & & & $\checkmark$ & \\
\hline 18 & Alika & & & & $\checkmark$ & \\
\hline 19 & Nizam & & & $\checkmark$ & & \\
\hline 20 & Nindy & & & & $\checkmark$ & \\
\hline
\end{tabular}


Table 3. Examples of creativity observation formats used during the 4 second meetings in the class

\begin{tabular}{|c|c|c|c|c|c|c|}
\hline \multicolumn{7}{|c|}{$\begin{array}{l}\text { Sheet of Mobis Creativity Observation } \\
\text { Class B Fatimah } \\
\text { Islamic An-Nisa Kindergarten Bandung } \\
\text { Fifth meeting }\end{array}$} \\
\hline \multirow{2}{*}{ No } & \multirow{2}{*}{ Name of puple } & \multirow{2}{*}{$\begin{array}{l}\text { Able to make their own } \\
\text { shapes }\end{array}$} & BB & MB & BSH & BSB \\
\hline & & & 1 & 2 & 3 & 4 \\
\hline 1 & Akmal Naufal F & & & & & $\checkmark$ \\
\hline 2 & Fadli & & & & & $\checkmark$ \\
\hline 3 & Fathiya & & & & & $\checkmark$ \\
\hline 4 & Bagas & & & & & $\checkmark$ \\
\hline 5 & Hasya & & & & & $\checkmark$ \\
\hline 6 & Azka & & & & & $\checkmark$ \\
\hline 7 & Ghailan & & & & & $\checkmark$ \\
\hline 8 & Alarick & & & & & $\checkmark$ \\
\hline 9 & Sabiq & & & & & $\checkmark$ \\
\hline 10 & Mutia & & & & & $\checkmark$ \\
\hline 11 & Naura & & & & & $\checkmark$ \\
\hline 12 & Naurah & & & & $\checkmark$ & \\
\hline 13 & Putri & & & & & $\checkmark$ \\
\hline 14 & Raja & & & & & $\checkmark$ \\
\hline 15 & Vale & & & & $\checkmark$ & \\
\hline 16 & Wangsa & & & & & $\checkmark$ \\
\hline 17 & Jian & & & & & $\checkmark$ \\
\hline 18 & Alika & & & & $\checkmark$ & \\
\hline 19 & Nizam & & & & $\checkmark$ & \\
\hline 20 & Nindy & & & & & $\checkmark$ \\
\hline
\end{tabular}

Other activities that are also considered an important factor in considering the final evaluation results Mobis play method is the retrieval of interviews with both parents and teachers involved in Mobis activities. Interviews with students are scheduled to take place after the Mobis playing method is finished or after the eighth day, while the interviews with the teacher can be carried out on the days of Mobis play or other days 
that are close together, of course with different hours. The materials or indicators that become the standard of interview, as shown in the example of Tables 4 and 5, as follows;

Table 4. Example of standard indicators / aspects studied in Interviews with parents of participants participating in the Mobis play method.

\begin{tabular}{|c|c|c|c|c|}
\hline \multicolumn{5}{|c|}{$\begin{array}{l}\text { Respondent name / The parent of : Lia Rislianingsih/Akmal } \\
\text { Gender } \\
\begin{array}{ll}\text { Age } & : \text { Perempuan } \\
\text { Occupation } & \text { : Housewife }\end{array}\end{array}$} \\
\hline No & Aspects to be observed & Yes & Rarely & No \\
\hline 1. & Does the child eat alone at home? & $\checkmark$ & & \\
\hline 2. & Do children bathe themselves? & & & $\checkmark$ \\
\hline 3. & Is the child able to button his own clothes? & $\checkmark$ & & \\
\hline 4. & $\begin{array}{l}\text { Do children tie their own shoelaces with a little } \\
\text { help from others? }\end{array}$ & $\checkmark$ & & \\
\hline $\begin{array}{l}5 . \\
6 .\end{array}$ & $\begin{array}{l}\text { Can the child comb her own hair? } \\
\text { Do children at home like to make various forms of } \\
\text { plasticine? }\end{array}$ & $\checkmark$ & & \\
\hline 7. & $\begin{array}{l}\text { Whether the child at home has a game tool } \\
\text { "Mobis"? }\end{array}$ & $\checkmark$ & & \\
\hline 8 & Does the child often play Mobis at home? & $\checkmark$ & & \\
\hline 9 & Does the child enjoy playing Mobis? & $\checkmark$ & & \\
\hline 10 & $\begin{array}{l}\text { Do parents know the schedule of mobis activities } \\
\text { at school? }\end{array}$ & $\checkmark$ & & \\
\hline 11 & $\begin{array}{l}\text { Is the child enthusiastic if there is a schedule of } \\
\text { Mobis activities in school? }\end{array}$ & $\checkmark$ & & \\
\hline
\end{tabular}


Table 5. Format of interview guide for teachers

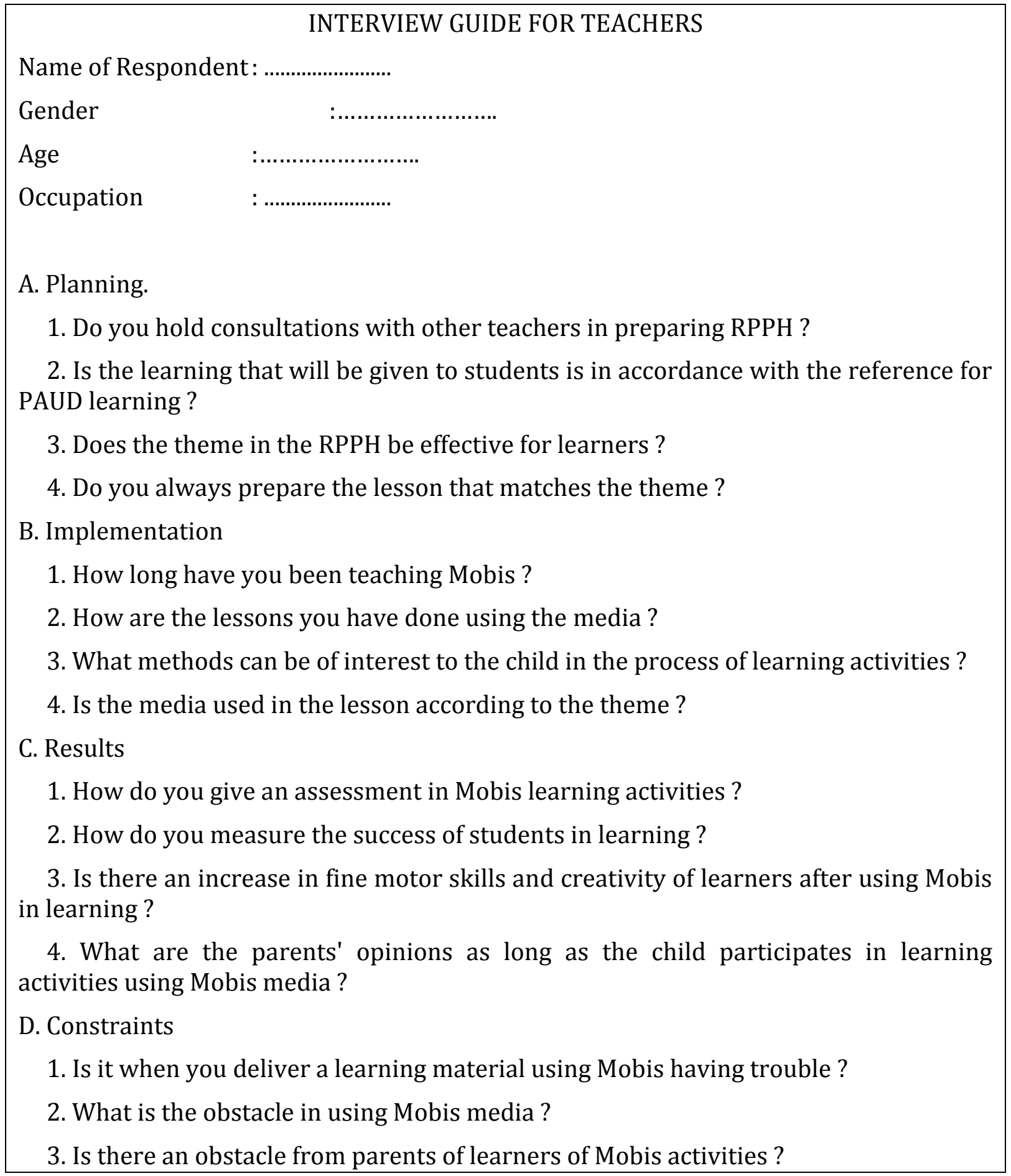

\section{OBSERVATION RESULTS}

Implementation of the core activities of assembling the blocks of Mobis at every meeting monitored smoothly with the creation of a calm atmosphere, serious, focused and fun. Having first given some guidance on how and the purpose will form what Mobis blocks, 
then the students look enthusiastic to start it. Implementation of Mobis design by given about 30 minutes only (figure 4).

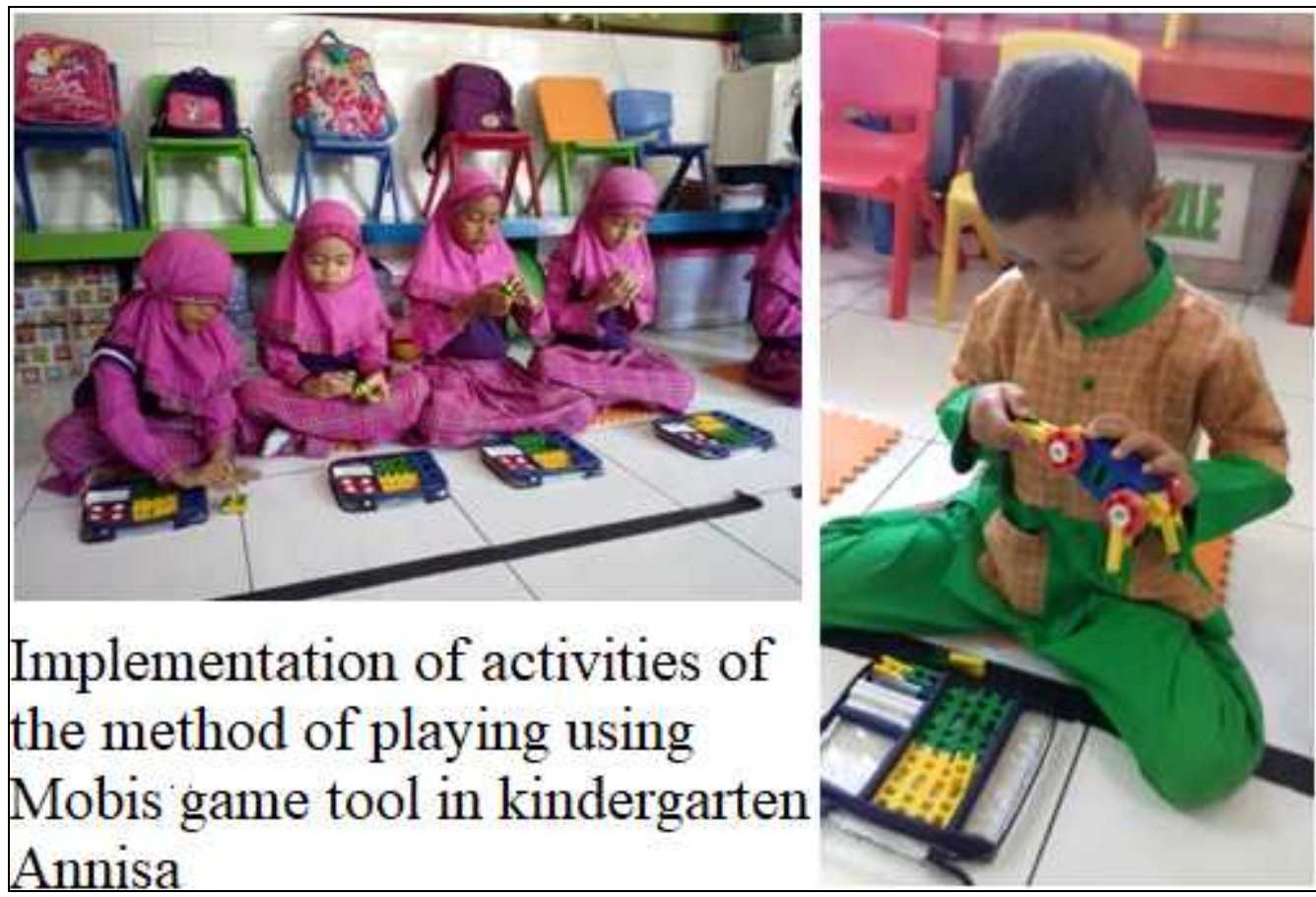

Figure 4. The atmosphere created calm, serious, focused and fun for students participating in the Mobis playing method.

The child's ability to develop fine motor and creativity in learning using Mobis's educative game tools is good enough. This can be seen from the evaluation conducted by the teacher at each completed activity during the eight meetings. In addition, the ability of children in developing fine motor and creativity can be seen from the assessment and analysis process of activities and work of children every meeting there is an increase in ability.

Fine motor evaluation is done by looking at the robustness and conformity with the direction of the teacher of the object that each child has, while the evaluation of creativity is seen from the idea or idea of forming itself without the direction of the teacher, how he can create various forms according to his imagination and can explain what which he made. For more details here is a recapitulation of the results of fine motor skills observation and children's creativity in the learning process using the Mobis educational game tool for eight meetings (table 6), which then the author of the reconstruction becomes the "sequence of day versus value of attainment / weighting" curve (figure 5 ).

Table 6. Recapitulation of Observation Results of Mobis Activities

\begin{tabular}{|c|c|c|c|c|c|c|c|c|c|}
\hline \multirow{3}{*}{ No } & \multirow{3}{*}{ Name } & & $\mathbf{M}$ & ic & & & & ivi & \\
\hline & & \multicolumn{8}{|c|}{ Meetings } \\
\hline & & 1 & 2 & 3 & 4 & 5 & 6 & 7 & 8 \\
\hline 1 & Akmal Naufal F & 3 & 4 & 4 & 3 & 4 & 4 & 4 & 4 \\
\hline
\end{tabular}




\begin{tabular}{|c|c|c|c|c|c|c|c|c|c|}
\hline \multirow{3}{*}{ No } & \multirow{3}{*}{ Name } & Fin & Mot & ric s & ills & & Cre & tivit & \\
\hline & & \multicolumn{8}{|c|}{ Meetings } \\
\hline & & 1 & 2 & 3 & 4 & 5 & 6 & 7 & 8 \\
\hline 2 & Fadli & 2 & 3 & 2 & 3 & 4 & 4 & 3 & 4 \\
\hline 3 & Fathiya & 4 & 4 & 4 & 3 & 4 & 4 & 4 & 4 \\
\hline 4 & Bagas & 3 & 3 & 2 & 3 & 4 & 4 & 4 & 4 \\
\hline 5 & Hasya & 3 & 3 & 2 & 3 & 4 & 4 & 4 & 4 \\
\hline 6 & Azka & 3 & 3 & 4 & 3 & 4 & 4 & 4 & 4 \\
\hline 7 & Ghailan & 4 & 0 & 4 & 3 & 4 & 3 & 4 & 3 \\
\hline 8 & Alarick & 3 & 2 & 2 & 3 & 4 & 4 & 4 & 4 \\
\hline 9 & Sabiq & 2 & 2 & 2 & 3 & 4 & 4 & 4 & 4 \\
\hline 10 & Mutia & 3 & 4 & 3 & 3 & 4 & 4 & 4 & 4 \\
\hline 11 & Naura & 3 & 2 & 2 & 3 & 4 & 3 & 4 & 3 \\
\hline 12 & Naurah & 2 & 2 & 3 & 2 & 3 & 3 & 3 & 4 \\
\hline 13 & Putri & 3 & 3 & 3 & 3 & 4 & 4 & 4 & 4 \\
\hline 14 & Raja & 2 & 3 & 3 & 3 & 4 & 3 & 3 & 4 \\
\hline 15 & Vale & 2 & 2 & 3 & 3 & 3 & 3 & 3 & 3 \\
\hline 16 & Wangsa & 3 & 4 & 4 & 4 & 4 & 4 & 4 & 4 \\
\hline 17 & Jian & 3 & 2 & 3 & 4 & 4 & 4 & 4 & 4 \\
\hline 18 & Naila & 3 & 2 & 3 & 3 & 3 & 3 & 3 & 4 \\
\hline 19 & Nizam & 2 & 2 & 3 & 3 & 4 & 4 & 4 & 4 \\
\hline 20 & Nindy & 3 & 3 & 3 & 3 & 4 & 4 & 4 & 4 \\
\hline & Average & 2.8 & $\begin{array}{c}2.6 \\
5\end{array}$ & $\begin{array}{c}2.9 \\
5\end{array}$ & $\begin{array}{c}3.0 \\
5\end{array}$ & $\begin{array}{c}3.8 \\
5\end{array}$ & $\begin{array}{l}3 . \\
7\end{array}$ & $\begin{array}{c}3.7 \\
5\end{array}$ & 3.85 \\
\hline Acl & vement values of & sults & & & & & & & \\
\hline & yet developed ), & ( st & t dev & lopir & & & & B ( & not \\
\hline
\end{tabular}




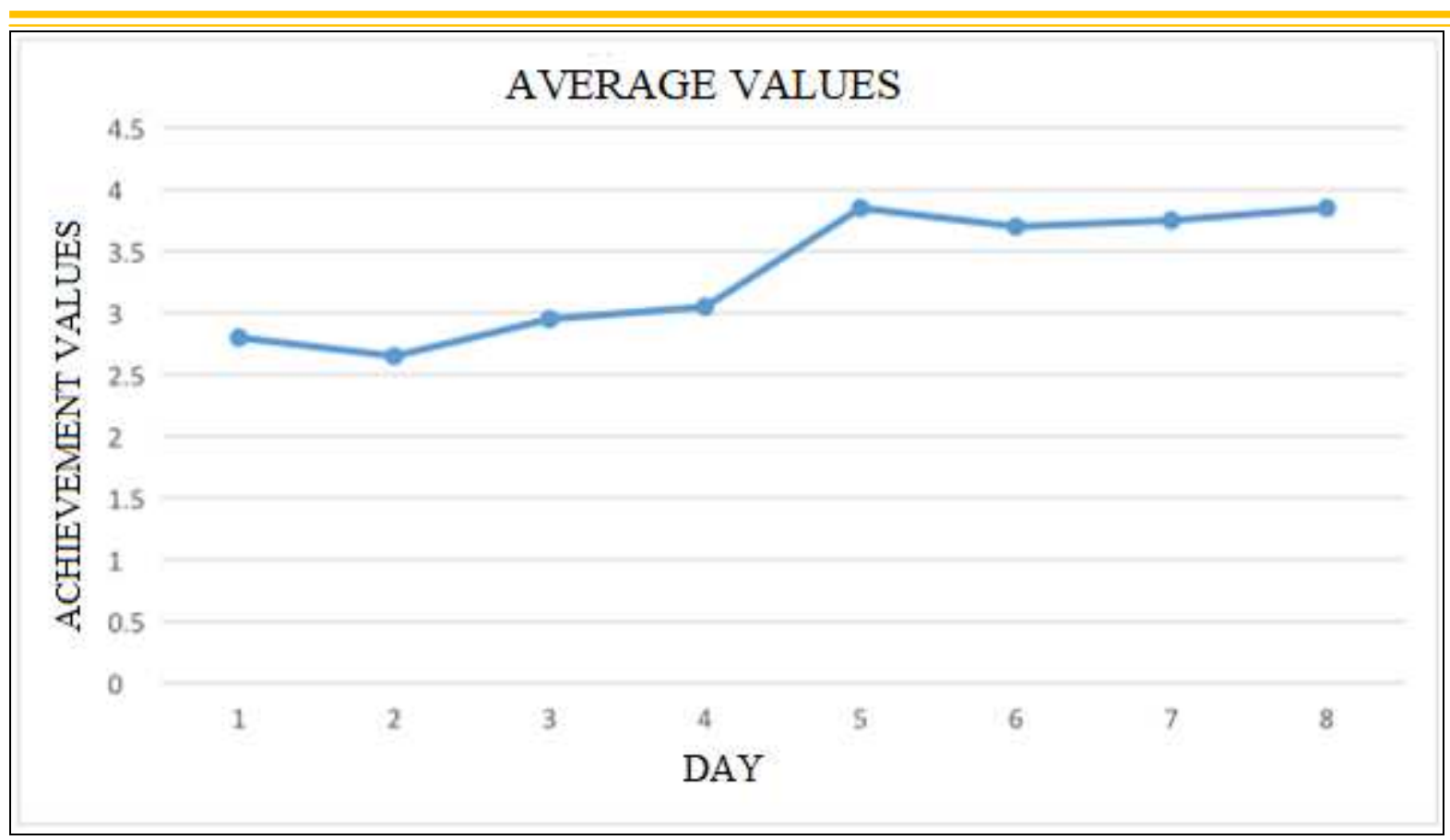

Figure 5. The average observation curve from the achievement / weighting score until the eighth week of meeting.

In table 6 it is observed that in general the weighted value is at a value in> 2.5 (MB) or about 3 (BSH). Except the value of Ghailan students (yellow box) at the second week meeting is 0 because it is absent, although the average student is 3 (BSH) to 4 (BSB). Similarly, as shown in Figure 5, the average observation curve from the achievement / weighting score until the eighth week of meeting is dominated by the achievement value $>3$, from the third to the last meeting. The average curve also shows an increasing trend-line for both fine motor skills and creativity. The prediction of this curve is that if the number of encounters more than 8 times combined with some modifications of the Mobis method is very likely to produce better creativity, as well as to improve its cognitive abilities.

Qualitatively from the distribution of scores in table 6, students' developmental abilities can be grouped into 3 rankings of achievement values of the highest: Wangsa that are only at the first encounter of 3 and so on are 4 (blue rows), then Vale is ranked the lowest with a value of 2 to 3 (red row rows), and the largest group of other students with moderate or average grades.

Figure 6 shows that the Wangsa has relatively monotonous but almost perfect curve characteristic. The student named Wangsa by the age of 6 this year looks very prominent compared to the others. 


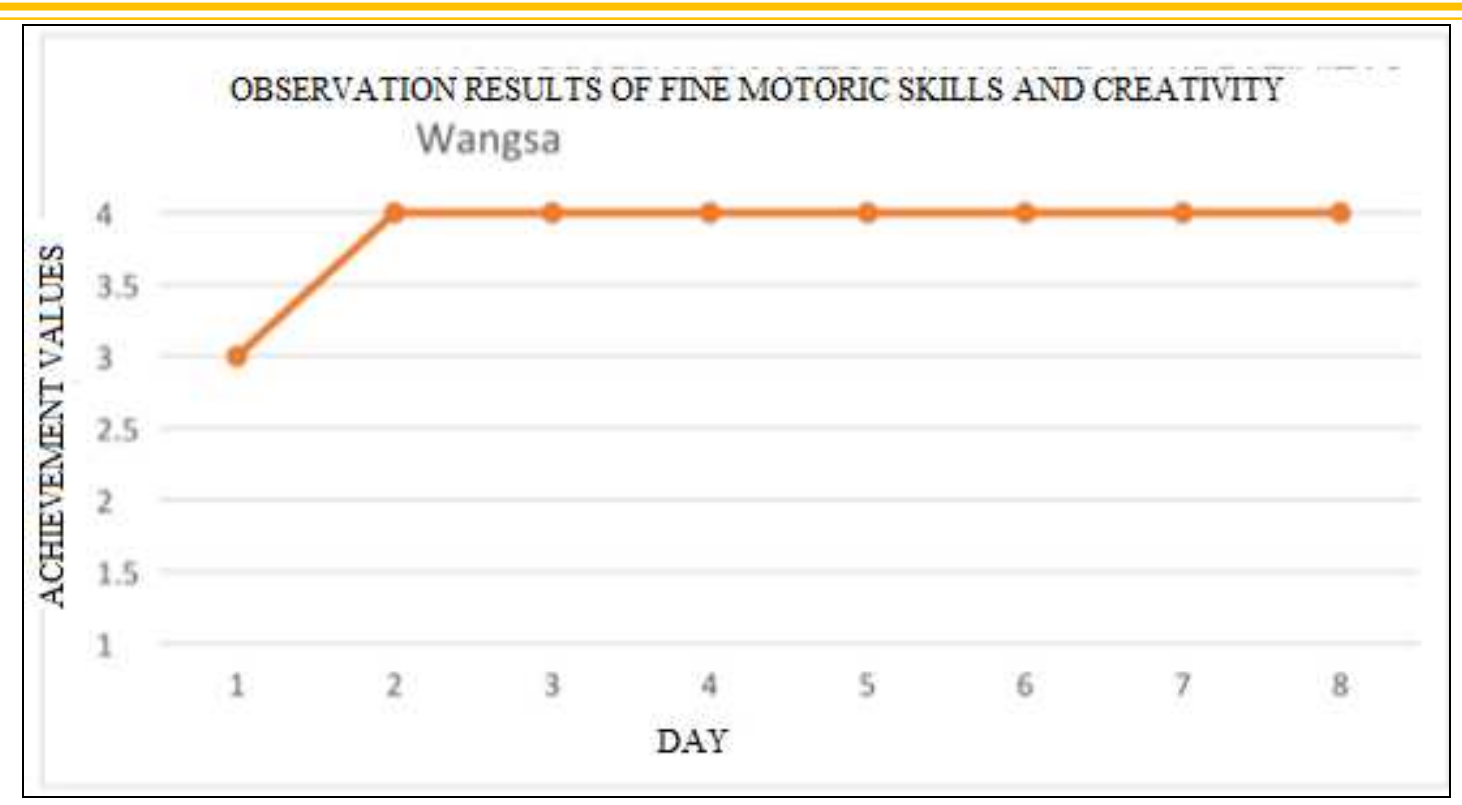

Figure 6. Progressive Achievement Curve of House looks almost perfect

From his age he already belongs to a mature early age and ready to start school in elementary school. From the information obtained from the interview with his parents, it was observed that the Wangsa were categorized as mature or starting to mature and were very ready to start elementary school. When linked to the three most influential environmental factors, namely family, school and community (Wiyani, 2016), what can be concluded from this case is that with a family background that plays a conducive role in the growth and development of early childhood as well as social around which has a positive effect on the environment and the role of kindergarten education institutions will produce fine motor indicators and almost perfect creativity. While the role of the Mobis playing method activity itself is as a media playing method that can provide an overview of the progress of fine motoric indicators and creativity,

On the other hand, it appears that there are students named Vale who are opposite the Wangsa less than 6 years of age and only reach a score of 3 from the third to the last meeting (figure 7). This achievement is lower than the average curve and with a curve profile that does not increase and is different from the trend line average curve. From the source of the interview data turned out Vale categorized as a rather spoiled child. Improvement only occurs in fine motorized achievements, while for creativity it is monotonous at value 3 or developing according to expectations (BSH). Predictable predictions from Vale are to increase the number of meetings so that there will likely be an increase in creativity. 


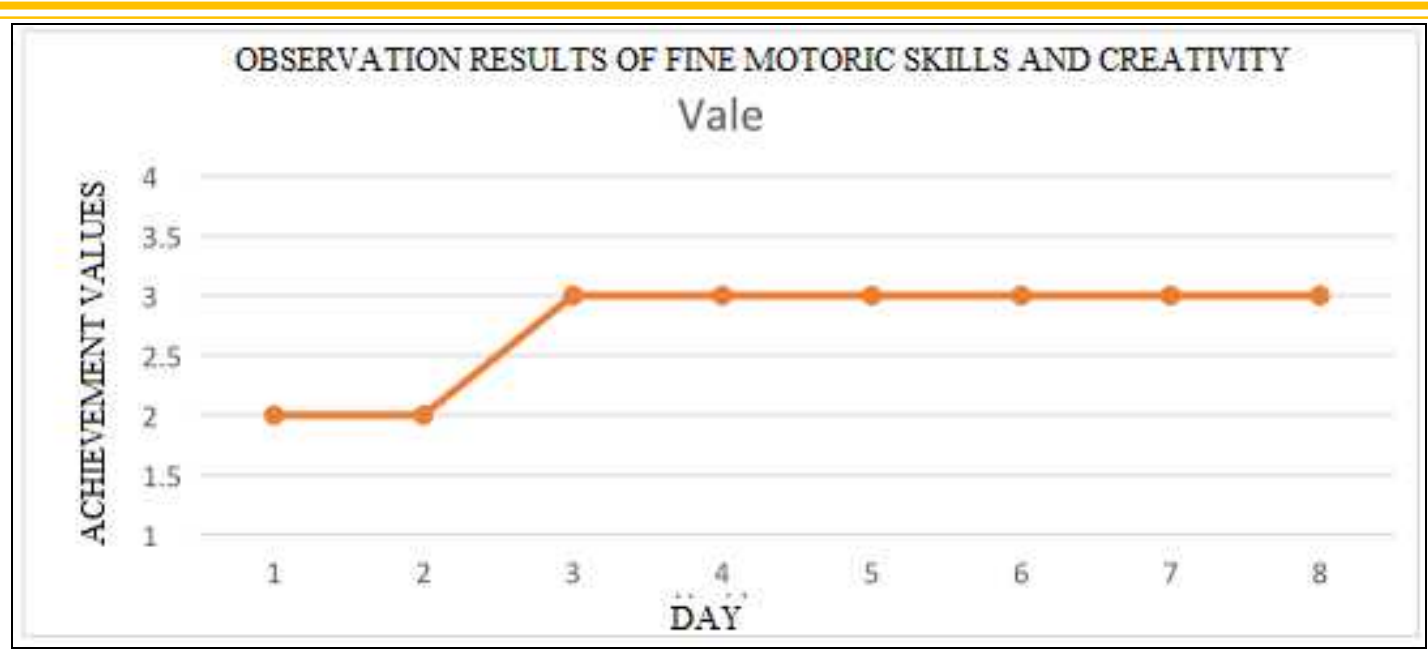

Figure 7. The curve of achievement progress from Vale that was observed to be less increased

The largest remaining student group (18 students) with a moderate or closest profile or average curve configuration is represented by an example of the performance curve from Naura (figure 8). Naura curve configuration can be considered as a representation of the general achievements of Fatimah Class B students.

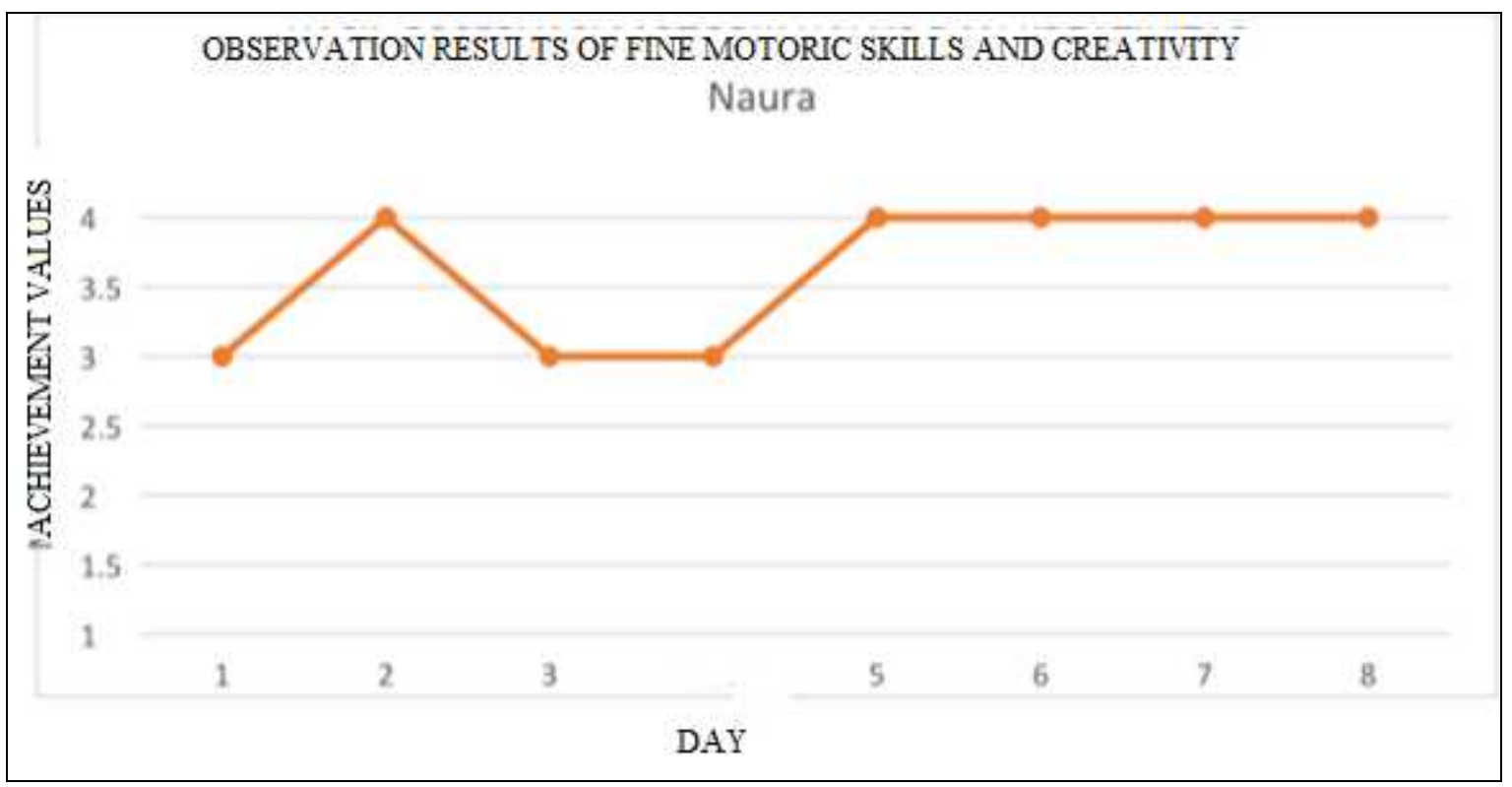

Figure 8. The progressive achievement curve of Naura as representative of the average configuration profile of the overall achievement curve

Curve fluctuations only occur in fine motor profiles, while creativity is monotonous with the highest achievement value $(4=\mathrm{BSB})$. In the Naura case, it was observed that learning with the Mobis playing method needed more meetings than learning to increase creativity, while the achievement of creativity had developed very well. The results of interviews with his parents indicate the influence of dominant family and 
community environment rather than the school environment. The observed condition is common in most Fatima Class B students with preschool age.

\section{Fine Motoric Skills Progress}

In table 7 , the observation results of playing activities with the Mobis method at meetings 1-4, fine motor development is more varied and the biggest increase reaches the BSH category. MB's performance dropped sharply from third to fourth, while the steepest increase also occurred in BSH from third to fourth. This means

Table 7. Recapitulation of Achievement of Fine and Creativity Motor Skills from Mobis Activities, seen from the Number of Students.

\begin{tabular}{|c|c|c|c|c|c|c|c|c|}
\hline Day & \multicolumn{4}{|c|}{ Fine motoric skills } & \multicolumn{4}{c|}{ Creativity } \\
\hline & BB & MB & BSH & BSB & BB & MB & BSH & BSB \\
\hline 1 & & 6 & 12 & 2 & & & & \\
\hline 3 & & 8 & 7 & 4 & & & & \\
\hline 4 & & 6 & 9 & 5 & & & & \\
\hline 5 & & 1 & 17 & 2 & & & & \\
\hline 6 & & & & & & & 3 & 17 \\
\hline 7 & & & & & & & 5 & 13 \\
\hline 8 & & & & & & & 3 & 17 \\
\hline
\end{tabular}

that training or learning with Mobis method is excellent for improving fine motor skills to achieve BSH. While achieving BSB may require a better basic mentality that is supported by the positive influence of family, community and school backgrounds so as to achieve a more mature basic mentality such as those in the House case.

\section{Development of Creativity}

Table 7 shows the generally excellent level of creativity outcomes (BSB), even from the seventh to the last meeting showing improvement. In table 6 the almost perfect average achievement rate is 3.8. The distribution of these values is qualitatively patterned very differently from those in the distribution of values for fine motor performance. Here achievements occur more in the category of BSB, while the smooth morik developed in the category of BSH. From this difference can the authors conclude that the development of thinking power of creativity better after practice or after having basic achievements in the initial meetings. This shows that initial recognition also results in the development of creative thinking.

\section{CONCLUSION}

1. Generally through Mobis activities can improve motoric skills Smooth and Creativity of children group B in kindergarten Islam An-Nisa Bandung

2. Mobis method proved effective enough to stimulate the ability Motorik Smooth dab Creativity in the development of Early Childhood. 
3. Implementation of Mobis Methods in An-Nisa Islamic Kindergarten is in accordance with educational programs that have been proclaimed both by local planning programs and national education programs.

4. In the development of mobis method can still be developed further, especially for the number of students more with a longer time.

5. Further collaboration between Kindergarten institutes and companies that specifically organize Mobis in the future can be applied more precisely targeted in different cultures of society.

\section{BIBLIOGRAPHY}

Akhyadi, A. S., \& Mulyono, D. (2018). PROGRAM PARENTING DALAM MENINGKATKAN KUALITAS PENDIDIKAN KELUARGA. ABDIMAS SILIWANGI, 1(1), 1-8.

Hariwijaya, M., 2009; PAUD Melejitkan Potensi Anak dengan Pendidikan Sejak Dini. Mahadika Publicity, Yogyakarta.

Hiladayani, Rini, dkk, 2009; Psikologi Perkembangan Anak. Universitas Terbuka, Jakarta. Indraswari, Lolita, 2015; Peningkatan Perkembangan Motorik Halus AnakUsia Dini Melalui Kegiatan Mozaik di Taman Kanak-kanak PembinaAgam. Jurnal Pesona PAUD Vol. 1. No.1.

Hurlock, Elizabeth B., 1978; Perkembangan Anak. Penerbit Erlangga, Jakarta.

Indraswari, Lolita, 2015; Peningkatan Perkembangan Motorik Halus Anak Usia Dini Melalui Kegiatan Mozaik di Taman Kanak-kanak Pembina Agam. Jurnal Pesona PAUD Vol. 1. No.1.

Kementerian Pendidikan Nasional, 2010; Peraturan Menteri Pendidikan Nasional Republik Indonesia nomor 58 tahun 2009 tentang Standar Pendidikan Anak Usia Dini (PAUD). Direktorat Pembinaan TK dan SD.

Kitab Undang-undang RI Nomor 20 Tahun 2003, tentang Sistem Pendidikan Nasional; Jakarta.

Koenarso, Dyah Ageng Pramesty, 2017; Penerapan Melipat, Menggunting, Menempel (3M) Dalam Upaya Meningkatkan Keterampilan Motorik Halus Anak. Jurnal PTK \&Pendidikan, Vol. 3 No. 1. Januari-Juni 2017, p1-8.

Munandar, Utami, 2009; Pengembangan Kreatifitas Anak Berbakat. Rineka Cipta, Jakarta.

Mutia, Diana, 2010; Psikologi Bermain Anak Usia Dini. Kencana Prenada Media Grup, Jakarta.

Ngalimun, Haris Fadillah, Alpha Ariani, 2013; Perkembangan dan Pengembangan Kreatifitas. Aswaja Pressindo, Yogyakarta.

Noorlaila, Iva, 2010; Panduan Lengkap Mengajar PAUD. PINUS, Yogyakarta.

Piaget, Jean, 2010; Psikologi Anak. Pustaka Pelajar, Yogyakarta.

Santrock, W. John, 1995; Life Span Development. PT. Erlangga, Jakarta. 
Saputra, Y.M. \& Rudyanto, 2005; Pembelajaran Kooperatif untuk Meningkatkan Keterampilan AnakTK. Direktorat P2TK2PT, Ditjen Pendidikan Tinggi, Departemen Pendidikan Nasional, Jakarta.

Semiawan, Conny R., 2009; Memupuk Bakat dan Kreatifitas Siswa Sekolah Menengah. Coramedia, Jakarta.

Sujiono, Bambang and Sumantri, M.S. and Aisyah, Siti and Tatminingsih, 2009; Metode Pengembang Fisik. Universitas Terbuka, Jakarta.

Sukmaningrum, I. A., 2015; Mengembangkan Ketrampilan Fisik Motorik Halus Anak Melalui Kegiatan Menjahit Untuk Usia 5-6 Tahun Semester I TK Karangrejo 03 Kecamatan Wungu Kabupaten Madiun Tahun Ajaran 2015/2016. Prosiding Seminar Nasional Pendidikan, Universitas Sebelas Maret Surakarta dan ISPI Wilayah Jawa Tengah.

Sumantri, 2005; Model Pengembangan Keterampilan Motorik Anak Usia Dini. Departemen Pendidikan Nasional, Direktorat Jenderal Pendidikan Tinggi, Direktorat Pembinaan Pendidikan Tenaga Kependidikan dan Ketenagaan Perguruan Tinggi, Jakarta.

Tedjasaputra, Meyke S., 2005; Bermain, Mainan dan Permainan. P.T. Grasindu, Jakarta.

Wiriaatmaja, Rochiati, 2005; Metode Penelitian Tindakan Kelas. PT. Remaja Rosdakara, Jakarta.

Wiyani, N.A., 2016; Konsep Dasar PAUD. Penerbit Gava Media, Yogyakarta.

Yamin,M. Dan Jamilah,S.S., 2010; Panduan Pendidikan Anak Usia Dini. Gaung Persada Pers, Jakarta. 